\title{
Chemical composition and nutritional value of the new citrus pomace feed additive
}

\author{
Oleksii Karunsky ${ }^{1}$, Igor Nikolenko ${ }^{1 *}$, Maria Madani $^{2}$,and Oleksii Danchuk ${ }^{1}$ \\ ${ }^{1}$ Odessa State Agrarian University, Odessa, Ukraine \\ ${ }^{2}$ Odessa National Academy of Food Technologies, Odessa, Ukraine
}

\begin{abstract}
Research aimed at studying the chemical composition and nutritional value of a new feed additive from citrus pomace was conducted. The article presents the results of research on the technological line of granulation of citrus waste, studies their chemical composition, determines the gross content of proteins, fats, assimilated carbohydrates, including simple sugars and identifies the effectiveness of use in the diets of farm animals. The positive influence of the technological line of citrus waste granulation has been established, which allows to obtain high quality granules. Chemical analysis of citrus granules showed that $100 \mathrm{~g}$ contains: proteins $-6.15 \mathrm{~g}$, fats $-0.99 \mathrm{~g}$, carbohydrates $-21.8 \mathrm{~g}$, of which simple sugars $14 \mathrm{~g}$, the energy value of this feed additive is Kcal $(\mathrm{kJ})-120.7$ (505.7). We believe that the data on the qualitative characteristics and nutritional value of feed additives from citrus pomace suggest that this additive can be used in cattle feeding.
\end{abstract}

\section{Introduction}

Domestic and world experience of increasing the production of livestock products and reducing their cost shows that in recent years an increase in animal productivity by $65 \%$ has been achieved by improving their feeding system and advanced housing technologies. It follows that the organization of rational full-fledged feeding of farm animals is one of the main conditions for further increase of their productivity $[3,5,9]$.

As the knowledge of the animal's need for nutrients increases, so does the concept of the level of a complete diet. Detailed norms and rations of feeding farm animals reflect modern knowledge, on the basis of which a scientifically sound and well-founded feeding system has been developed [4].

Full supply of animals with all nutrients, minerals and biologically active substances, determines not only the level of productivity, but also the amount of feed costs for production [5].

With the transfer of animal husbandry to an industrial basis, it is important to develop a system of complete feeding of animals, which ensures their high productivity. It is established that the animal body needs the optimal amount of nutrients and biological substances [4].

Every year the science of feeding develops tools for the use of various biological and chemical feed additives. High productivity of animals, support of reproductive functions of an organism, effective use of forages is impossible without inclusion in a diet of forage additives which provide necessary level of biologically complete feeding. They are a mandatory ingredient in any diet for farm animals $[6,7]$.
Data on the biological role of individual feed additives, their interaction with other nutrients, dosage taking into account the species and age of animals, methods of administration, the impact on productivity and product quality are necessary for qualified use [8].

The use of supplements also helps to save feed, as a scientifically sound combination of all nutrients and biologically active substances in the diet provides the fullest digestion and assimilation by the body, compared with the components of the diet, which are used separately, fed separately.

The production of feed additives allows to increase the high-energy properties of the diet, to effectively use the ingredients of the diet.

The possibility of preparing feed additives in the form of granules avoids self-sorting of components and overdose of micronutrients and improve the consumption of feed ingredients.

In this regard, it is important to study the chemical composition and nutritional value of citrus pomace and the effectiveness of their use for feed purposes in feeding farm animals.

The main raw materials for the production of new feed additives are citrus pomace.

The use of new feed additives in the diets of farm animals is possible only after studying their effectiveness in feeding animals, the impact on health and productivity and their registration in Ukraine.

The purpose of our work was to develop a scheme of the technological line of granulation of citrus waste, to establish their chemical composition. To achieve this goal, the task of our research was: 
- determination of the gross content of proteins, fats, assimilated carbohydrates, BAS in particular simple sugars;

- identification of the effectiveness of use in the diets of farm animals.

\section{Materials and methods}

The experimental part of the work on the development of the technological line of granulation of citrus waste was performed on the basis of LLC "LAMPOCHKA" of the city of Chernomorsk, Odessa region.

Laboratory studies to study the chemical composition of citrus granules were conducted in the Research and Service Company "OTAVA" in 2019.

The fat content in the sample №1157 / 3 was determined according to the method of GOST 329052014 (ISO 6492: 1999) "Feed, compound feedstuff, feedstock. Method for determination of crude fat content", by extracting crude fat from the product with a solvent, subsequent removal of the solvent, drying and weighing the extracted fat $[9,10]$.

The protein content in sample $1157 / 3$ was determined according to the method of GOST 13496.4-93 " Feed, compound feedstuff, feedstock. Methods for determining the content of nitrogen and crude protein" by measuring the nitrogen content and converting the result to the protein content.

The total content of digestible carbohydrates was defined as the sum of simple sugars and carbohydrates that are easily hydrolyzed ("inverted"). Prior to hydrolysis, the content of simple sugars is determined, followed by the determination of the total invert sugar, which consists of the original simple sugars contained in the sample and the simple sugars formed by hydrolysis.

The content of simple sugars in sample $1157 / 3$ was determined according to the method of GOST 5903-89 "Confectionery". Methods for determination of sugar by measuring the amount of monovalent copper oxide formed by the iodometric method due to the reaction with reducing substances (simple sugars). Accordingly, the gross content of digestible carbohydrates was determined in a similar manner, after acid hydrolysis of dissolved poly- and oligosaccharides to glucose.

BAS, mineral and vitamin composition of citrus pomace was determined by generally accepted methods $[9,10]$.

Methods for determining the above indicators involve working with crushed dry sample. The sample was pre-dried to constant weight at $65^{\circ} \mathrm{C}$ and ground to a powder.

To convert the measurement results to the native state of the sample, the content of volatile substances and water in it was determined. The sample was dried on an automatic moisture meter to a constant weight at a temperature of $65^{\circ} \mathrm{C}$. The moisture and volatile matter content was $2,55 \pm 0,35 \%$ by weight of the sample.

\section{Results and discussion}

Taking into account the useful properties of citrus pomace, a method of processing citrus pomace into feed additives was developed. When citrus was extruded, up to $55-60 \%$ of moisture evaporated from the extrudate, which ensured the moisture content in the feed additive was not more than $12-13 \%$, which allows to store the feed additive for a long time.

The humidity of the mixture before extrusion was not more than $17-19 \%$. The introduction into the mixture of $20 \%$ sunflower meal with a moisture content of $10 \%, 3-$ $7 \%$ molasses with a moisture content of $20 \%$, citrus extrudate $75 \%$ with a moisture content of $15 \%$, made it possible to obtain a mixture with a moisture content of $15 \%$.

Given the results of studies of citrus feed additives, the most effective is the inclusion in the feed additive: sunflower meal $-20 \%$, molasses $-5 \%$ and $75 \%$ of citrus fruits.

Citrus pomace is separately prepared for processing, crushed on a grater to a particle size of 2-3 mm, homogenized and dosed, after which sunflower meal, molasses is mixed in a mincer to form a homogeneous mixture.

The granular process is the compression of a homogeneous mass by pressing rollers and the surface of the matrix with round holes. Compression takes place under the action of moisture, heat and pressure, at this time the homogeneous mixture acquires thermoplastic properties and through the holes of the matrix takes the form of granules.

The temperature of the obtained granules was +60 $80^{\circ} \mathrm{C}$, after that they are sent to the cooler, where they are cooled to a temperature of $18-20{ }^{\circ} \mathrm{C}$. The humidity of the cooled granules did not exceed 6-7\%. The floury fraction is obtained after sieving the granules, sent for further granulation. A sample of cylindrical granules with a diameter of 5-6 mm was obtained in Fig. 1.

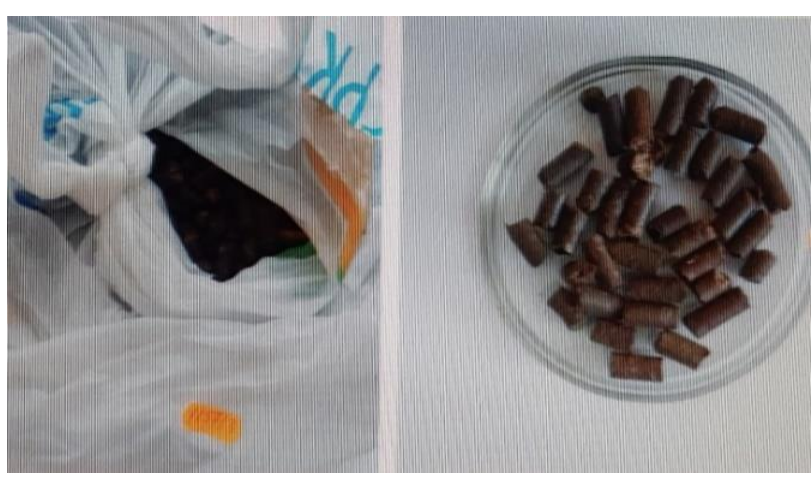

Fig. 1. Photo of the obtained sample.

To use the obtained citrus granules for feed purposes, we conducted a study of chemical composition and nutrition.

The results of determining the content of proteins, fats and carbohydrates are listed on the native state of the sample №1157/3 and the result of calculating the energy value per $100 \mathrm{~g}$ of product are shown in table 1 .

Chemical analysis of citrus granules showed that 100 g contains: protein $-6.15 \mathrm{~g}$, fat $-0.99 \mathrm{~g}$, carbohydrates - 
$21.8 \mathrm{~g}$, of which simple sugars $14 \mathrm{~g}$, the energy value of this feed additive is Kcal (kJ) - 120.7 (505.7).

The mineral and vitamin composition of citrus per 100 grams of product are shown in table 2 .

Scientific and economic experiment to study the effectiveness of the use of citrus granules in the diets of dairy cows was carried out for 105 days by the group method according to the scheme shown in table 3 .

Table 1. Chemical composition and energy value of the sample №1157 / 3 per $100 \mathrm{~g}$ of product (for the native state of the sample)

\begin{tabular}{|c|c|}
\hline Indicators, units of measurement & Value (per $100 \mathrm{~g}$ ) \\
\hline Protein, $g$ & $6,15 \pm 0,03$ \\
\hline Fat, $g$ & 0 \\
\hline $\begin{array}{c}\text { The content of digestible } \\
\text { carbohydrates ** (of them simple } \\
\text { sugars), g }\end{array}$ & $21,8 \pm 0,04(14,0 \pm 0,1)$ \\
\hline Energy value, kcal $(\mathrm{kJ})$ & $120,7(505,7)$ \\
\hline
\end{tabular}

Feeding of cows was double, carried out individually, taking into account the specified feed and their residues. The total nutritional value of the rations was determined by detailed norms, the milk yield of cows was carried out individually once every 10 days. The average daily milk yield for the study was taken twice in the transition period and in the main and in the final at the end of each period in proportion to the amount of milk. Food consumption during the experiment was quite high. The composition and nutritional value of the average daily rations of experimental animals are shown in table 4.

The data in table 3 indicate that when using a feed additive from citrus pomace, the nutritional value of the diet is improved by the sugar - protein ratio $(0,62: 1$ against $0,8: 1,2)$.

Table 2. Mineral and vitamin composition of citrus sample №1157/3 per 100 grams of product

\begin{tabular}{|c|c|c|}
\hline Vitamins & Macronutrients & Trace elements \\
\hline $\mathrm{A}-0,05 \mathrm{mg}$ & $\mathrm{K}-197,0 \mathrm{mg}$ & $\mathrm{Fe}-0,3 \mathrm{mg}$ \\
\hline $\mathrm{B}_{1}-0,04 \mathrm{mg}$ & $\mathrm{Ca}-34,0 \mathrm{mg}$ & $\mathrm{Na}-13,0 \mathrm{mg}$ \\
\hline $\mathrm{B}_{2}-0,03 \mathrm{mg}$ & $\mathrm{Mg}-13,0 \mathrm{mg}$ & $\mathrm{Cl}-3,0 \mathrm{mg}$ \\
\hline $\mathrm{B}_{3}-0,3 \mathrm{mg}$ & $\mathrm{P}-23,0 \mathrm{mg}$ & $\mathrm{B}-180 \mathrm{mcg}$ \\
\hline $\mathrm{B}_{6}-0,006 \mathrm{mg}$ & $\mathrm{S}-9,0 \mathrm{mg}$ & $\mathrm{J}-2,0 \mathrm{mcg}$ \\
\hline $\mathrm{B}_{9}-5,0 \mathrm{mcg}$ & - & $\mathrm{Co}-1,0 \mathrm{mcg}$ \\
\hline $\mathrm{C}-60,0 \mathrm{mg}$ & - & $\mathrm{Mn}-30,0 \mathrm{mcg}$ \\
\hline $\mathrm{E}-0,2 \mathrm{mg}$ & - & $\mathrm{Cu}-67,0 \mathrm{mcg}$ \\
\hline $\mathrm{H}-1,0 \mathrm{mcg}$ & - & $\mathrm{F}-17,0 \mathrm{mcg}$ \\
\hline $\mathrm{PP}-1,0 \mathrm{mcg}$ & - & $\mathrm{Zn}-200,0 \mathrm{mcg}$ \\
\hline
\end{tabular}

Dairy productivity of cows is shown in table 5 . As can be seen from table 5, the average daily milk yield was higher in cows of the research group by $1.8 \mathrm{~kg}$ or $15.5 \%$. Therefore, the effectiveness of feeding dairy cows with a feed additive from citrus feed for 105 days of scientific and economic experiment had a positive effect on milk productivity. The cost of feed for milk production of $4 \%$ fat was almost the same 0.97-0.98 feed units.
Table 3. The scheme of the experiment

\begin{tabular}{|c|c|c|c|c|}
\hline Group & $\begin{array}{c}\text { Number } \\
\text { of } \\
\text { animal } \\
\text { heads }\end{array}$ & $\begin{array}{c}\text { Equalization } \\
\text { period (15 } \\
\text { days) }\end{array}$ & $\begin{array}{c}\text { Main } \\
\text { period } \\
(60 \\
\text { days) }\end{array}$ & $\begin{array}{c}\text { Final } \\
\text { period } \\
\text { of 30 } \\
\text { days) }\end{array}$ \\
\hline Control & 10 & $\begin{array}{c}\text { the basic } \\
\text { ration }\end{array}$ & $\begin{array}{c}\text { the } \\
\text { basic } \\
\text { ration }\end{array}$ & $\begin{array}{c}\text { the } \\
\text { basic } \\
\text { ration }\end{array}$ \\
\hline Experimental & 10 & $\begin{array}{c}\text { the basic } \\
\text { ration } \\
\text { the } \\
\text { basic } \\
\text { ration } \\
+1,5 \mathrm{~kg} \\
\text { citrus } \\
\text { pomace }\end{array}$ & $\begin{array}{c}\text { the } \\
\text { basic } \\
\text { ration }\end{array}$ \\
\hline
\end{tabular}

Table 4. The composition and nutritional value of the average daily rations of experimental animals

\begin{tabular}{|c|c|c|}
\hline \multirow{2}{*}{ FEED } & \multicolumn{2}{|c|}{ GROUPS } \\
\cline { 2 - 3 } & Control & Experimental \\
\hline corn silage, $\mathrm{kg}$ & 30 & 30 \\
\hline wheat straw, kg & 2 & 2 \\
\hline sainfoin hay, kg & 3 & 3 \\
\hline compound feed, kg & 3 & 2 \\
\hline citrus supplement, kg & - & 1.5 \\
\hline salt, g The ration contains: \\
\hline \multicolumn{2}{|c|}{} \\
\hline feed units, kg & 16,5 & 100 \\
\hline digestible protein, g & 1250 & 16,2 \\
\hline dry substances, kg & 17,2 & 1185 \\
\hline Ca, g & 152,4 & 148,3 \\
\hline F, g & 78,4 & 81,2 \\
\hline fiber, \% & 16,4 & 16,7 \\
\hline Sugar-protein ratio & $0,62-1$ & $0,8-1,2$ \\
\hline
\end{tabular}

Table 5. Dairy productivity of cows

\begin{tabular}{|c|c|c|}
\hline \multirow{2}{*}{ Indexes } & \multicolumn{2}{|c|}{ Groups } \\
\cline { 2 - 3 } & 1 Control & 2 Experimental \\
\hline Average daily hopes, $\mathrm{kg}$ & 11,6 & 13,4 \\
\hline The fat content in milk, \% & 3,8 & 3,8 \\
\hline $\begin{array}{c}\text { The protein content in } \\
\text { milk, } \%\end{array}$ & 3,64 & 3,61 \\
\hline $\begin{array}{c}\text { Feed costs per 1 kg of milk } \\
\text { 4\% fat, feed. units }\end{array}$ & 0,98 & 0,97 \\
\hline
\end{tabular}

\section{Conclusion}

1. Studies indicate a positive impact of the technological line of granulation of citrus waste, which allows to obtain high quality granules. $100 \mathrm{~g}$ contains: proteins $6.15 \mathrm{~g}$, fats - $0.99 \mathrm{~g}$, carbohydrates - $21.8 \mathrm{~g}$, of which simple sugars $14 \mathrm{~g}$, the energy value of this feed additive is $\mathrm{Kcal}(\mathrm{kJ})-120.7$ (505.7).

2. When using a feed additive from citrus pomace, the nutritional value of the diet is improved by sugar protein ratio (0.62: 1 vs. $0.8: 1.2)$.

3 . Introduction to the diet of dairy cows feed additives from citrus pomace during stable lactation increases the average daily hope by $1.8 \mathrm{~kg}$ or $15.5 \%$, feed costs for 
milk production of $4 \%$ fat was almost the same $0.97-0.98$ feed units.

\section{References}

1. V.M. Kandyba, I.I. Ibatul, V.I. Kostenka, Theory and practice of normalized feeding of cattle, (PP Ruta, Zhytomir, 2012)

2. A. Kotlyar, Pig breeding, 4, 20-23 (1994)

3. V.Yu. Chumachenko, S.V. Stoyanovskyy, P.Z. Lahodyuk [et al.], Guide to the use of biologically active substances in animal husbandry ( Harvest, Kyiv, 1989)

4. V.Y. Hnoevoy, A.K. Tryshen, Y.V. Hnoyevoy, Biomorphological organization and nutritional value of feed ( Kharkiv: FLP Borovyn A.V., (2017)
5. V.V. Pan'ko, The use of a complex and feed additive from non-traditional raw materials in the diets of young pigs ( Dissertation, Simferopol, 1995)

6. H. Humenyuk, Feed industry, 3, 28-29, (1997)

7. B.V. Yehorov, O.I. Shapovalenko, A,V, Makaryns'ka, Premix production technology. Handbook (Center for Educational Literature, Kyiv, 2007)

8. F.Y. Svezhentsov, V.N. Korobko, Unconventional feed additives ( Art-Press, Dnepropetrovsk 2004)

9. V.K. Kononenko, I.I. Ibatulin, V.S. Patrov, Workshop on the basics of scientific research in animal husbandry ( Higher Education, Kyiv 2003).

10. V.M. Sheyko, N.M. Kushnarenko, Organization and methods of research: Textbook ( Knowledge, Kyiv, 2004) 